\title{
Large Scale Public Welfare Schemes for enhancing employability in SAARC Countries: a SWOT Analysis
}

\author{
Sundeep Kumar ${ }^{1}$, Monica Sharma ${ }^{2}$, Awadhesh Kumar Bhardwaj ${ }^{3}$ and G S Dangayach ${ }^{4}$ \\ Department of Management Studies, MNIT, Jaipur \\ sundeep.mnit@ymail.com, monicasharma.mnit@gmail.com, \\ awbh2001@gmail.com, dangayach@gmail.com
}

\begin{abstract}
With the growing population, the problem of unemployment is escalated. To fight with this problem every governmental body launches various Public Welfare Schemes (PWS) from year to year for welfare of poor or below poverty line population i.e. giving wages by taking work.PWS sometimes referred as public aid and social support for all citizens. Hence, it is very pertinent to understand which PWS is useful for which sector. Through this paper, an attempt is made to outline various PWS pertaining to SAARC nations only and with the help of SWOT analysis various parameters are identified like Strength, Weakness, opportunities and threats which will further helps in understanding the base of particular PWS. Lastly based on SWOT analysis discussion part is done in which general comparison of various PWS is done. Results will help in making understand which PWS carries how much importance and capability of generating employability and entrepreneurship.
\end{abstract}

Indexing terms/Keyword: Public Welfare Schemes (PWS); SAARC; SWOT analysis; Employability; Social welfare.

Language: English

ISSN: 2321-1091

Volume: ... Issue: ...

Journal: JOURNAL OF SOCIAL SCIENCE RESEARCH

Publisher: CIRWORLD

Website: https://cirworld.com

This work is licensed under a Creative Commons Attribution 4.0 International License.

\section{Introduction}

The concept that Public Welfare Scheme (PWS), framed as one of the strong social safety system through which redistribution of wealth and meaningful employment is generated. According to Devereux and Solomon (2006), several nations are gradually implementing several strategies to fight increasing poverty and unemployment.PWS sometimes referred as public aid and social support for all citizens. Generally, welfare is largely provided by the government groups in developed countries and lesser part is provided by social groups, charities and others inter-governmental organizations. Similarly, as per McCord (2008), PWS included all the activities, which execute the wages payment in return of labor whether by the state or by any state agent. Subbarao (2001) defined PWS in terms of World Bank as schemes in which participants obtain benefits if they work. These schemes or programmes include employment at a very low wage rate to fight against poverty. Therefore, PWS are proposed to provide a basic income to all workers in order to meet their subsistence needs. PWS could be seen in various forms-food-for-works (FFW), cash-for-work (CFW), agricultural inputs (fertilizers and seeds) for work (as in the Malawian Government's) or Inputs for Assets (IFA) programmed (UK DFID, 2004). 
After knowing the importance of PWS in general, it is pertinent to understand various PWS schemes running in developed and developing countries. So, through this paper an attempt is made to classify all major PWS of SAARC countries i.e. Afghanistan, Bangladesh, Bhutan, India, Maldives, Nepal, Pakistan, Sri Lanka and with the help of SWOT analysis various parameters of all schemes are compared.

This paper comprises in six sections. Section1 deals with the introduction part which discusses the concept of PWS and objective of paper. In section 2, literature pertaining to Public Welfare Schemes (PWS) with their typology of design and underlying central objectives was reviewed. A comparative study of public welfare works/schemes or programs in SAARC countries are discussed in section 3. In section 4 SWOT analysis of PWS of SAARC countries were done. Discussion regarding SWOT analysis is underlined in section 5 , while conclusion is done in the last section of this paper.

\section{Literature Review}

PWS generally surrounds with the two major elements, namely social security that includes social insurance and social assistance, and other general social services such as health care, education, housing services, and social works. Although nowadays the state plays an important role in the provision of social welfare, there is still an extensive debate on this subject. It is argued that the provision of welfare is a part of the basic reason why government should exist at all as there is a lack of incentive for self-interested contributions (Olson 1971), and for the private sector's involvement through normal market mechanisms. Coming in favor Cawson (1982) argues that the state can involve itself in social welfare provision under three modalities, namely direct provision, facilitating the private provision and mixed model which is known as 'welfare pluralism. According to many authors (Spicker, 1988; Dreze and Sen, 1991; Trattner, 1994; Whitaker and Federico, 1997) one can distinguish three functions of PWS, namely remedial, preventive, and supportive, and three kinds of services, namely income maintenance, in-kind services, and personal social services.

2.1 Taxonomy of PWS: - McCord (2008) proposed taxonomy of PWS, in which PWPs are grouped into four broad types:

2.1.1. Providing single short-term episode of employment: As per McCord (2008), these short-term schemes offer basic social protection like risk coping or protective forms. Such kinds of schemes already implemented in many countries like have Bangladesh and other Southern Asian states (e.g. Akal Rahat Yojna frequently implemented in Rajasthan (India)) in response to climatic shocks.

2.1.2. Government employment schemes to offer some form of employment guarantee at large scale: In these types of scheme government offers guarantee employment. Employment Guarantee Schemes are a subset of Government Employment Programme (GEPs), in which the state guarantees any running part of employment on demand to those who are eligible. Such types of programmes are currently operational in several states in India like the MEGS as well as on the national scale National rural employment guarantee programme NREGP.

2.1.3. Programs supporting the enlargement of labour in infrastructure sector: These types of schemes are exclusively formed for infrastructure sector. The work of the Ethiopian Rural Roads Authority (ERRA), the AGETIP (Agenced execution des Travaux Internet Public contre le sous-emploi) in Senegal, related AFRICATIP-supported programmes in Western Africa, all promote the use of labour-based techniques in the infrastructure sector and are typical of this type of intervention (McCord, 2008).

2.1.4. The Promotion of Employability: McCord (2008) argues that this type of approach is basically a mix of supply-side constraints to employment. This type of PWS promotes work place experience and skills formation among the unemployed and advances the employability of workers. These schemes are principally adopted by organization of Economic Cooperation and Development (OECD) countries time when unemployment hit high. These schemes provide sufficient numbers of jobs for the unemployed if they are adequately reskilled and supported.

\section{Saarc Public Welfare Schemes}


PWS refers to the provision of social services, i.e. 'those means developed and institutionalized by society to promote the ends, which are wholly or primarily social' (Townsen 1976). More specifically, Baker (1991) defines public welfare as programs that help people to meet their economic, social, educational, and health needs. According to Spicker (1988) and Whitaker and Federico (1997) PWS is organized and operates according to three principles, namely collective responsibility, universality and selectivity. Collective responsibility is the central principle, which requires risk sharing and redistribution among members of society. The principle of universality means in theory social welfare services shall be available to all the needy, who need them (Timmuss 1968). Selectivity means that social welfare services shall be given to the neediest, while excluding the others (Spicker 1988).

As per (McCord, 2007) objectives of PWS can be grouped into four broad categories-
(i) Social protection
(ii) Employment generation
(iii) Development of skills
(iv) Political stabilization

The aim here is to study social policy initiatives like Employment Guarantee Schemes (EGSs) and Livelihood Generation Programmes (LGPs), and other social protection programmes in accordance with the geographical set-up. Now let us understand various PWS of SAARC countries (Afghanistan, Bangladesh, Bhutan, India, Maldives, Nepal, Pakistan, Sri Lanka).

3.1.1 PWS of Bangladesh: - Bangladesh, officially the People's Republic of Bangladesh, is a country in South Asia. It is bordered by India on three sides and Myanmar to the southeast; the Bay of Bengal forms the southern coastline. Together with the Indian state of West Bengal, it comprises the ethno-linguistic region of Bengal. The name Bangladesh means "Country of Bengal". There are some public welfare schemes are launch for public welfare out of which some are discussed in Table 1 PWS of Bangladesh: -

\section{Table 1 PWS of Bangladesh}

\begin{tabular}{|c|c|c|c|c|}
\hline S.No. & Scheme & Sector & $\begin{array}{l}\text { Year of } \\
\text { Starting }\end{array}$ & Key Provisions \\
\hline 1. & $\begin{array}{l}\text { Food for Work Programme } \\
\text { (FFWP) }\end{array}$ & $\begin{array}{l}\text { Social } \\
\text { Protection }\end{array}$ & 1974 & $\begin{array}{l}\text { Creating employment for landless } \\
\& \text { land-poor and slack season } \\
\text { damage-control }\end{array}$ \\
\hline 2. & $\begin{array}{l}\text { Rural Maintenance } \\
\text { Programme (RMP) }\end{array}$ & $\begin{array}{l}\text { Social } \\
\text { Protection }\end{array}$ & 1983 & $\begin{array}{l}\text { Cash for work in a public } \\
\text { announcement for recruitment }\end{array}$ \\
\hline 3 & $\begin{array}{l}100 \text { Days } \quad \text { Employment } \\
\text { Generation } \\
(100 \mathrm{EGP})\end{array}$ & Employment & $\begin{array}{l}\text { 2008-09 } \\
\text { Financial } \\
\text { Budget }\end{array}$ & $\begin{array}{l}\text { Providing at least } 100 \text { days } \\
\text { employment for rural extreme } \\
\text { poor }\end{array}$ \\
\hline 4. & $\begin{array}{l}\text { Employment Generation } \\
\text { Programme for Hard-Core } \\
\text { Poor (EGP-HCP) }\end{array}$ & Employment & $\begin{array}{l}2009-10 \\
\text { Financial } \\
\text { Budget }\end{array}$ & $\begin{array}{l}\text { Same as } 100 \mathrm{EGP} \text { * essentially the } \\
\text { old programme in a new } \\
\text { framework }\end{array}$ \\
\hline 5. & 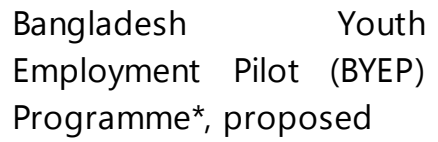 & Employment & $\begin{array}{l}\text { December, } \\
2008\end{array}$ & $\begin{array}{l}\text { Develop youth employment base } \\
\text { in } 3 \text { sectors namely Horticulture, } \\
\text { Aquaculture \& Leather products }\end{array}$ \\
\hline
\end{tabular}


3.1.2 PWS of Bhutan: Bhutan and four other landlocked Asian countries (Afghanistan, Laos, Mongolia, and Nepal) were granted a special status as "least developed landlocked countries" by the UN Economic and Social Commission for Asia and the Pacific (ESCAP) in coordination with the United Nations Conference on Trade and Development (UNCTAD) and UNDP. Table 2 PWS of Bhutan discusses few PWS initiated by Bhutan government.

\section{Table 2 PWS Of Bhutan}

\begin{tabular}{|l|l|l|l|l|}
\hline S.No. & Scheme & Sector & $\begin{array}{l}\text { Year of } \\
\text { starting }\end{array}$ & Key Provisions \\
\hline 1 & $\begin{array}{l}\text { Apprenticeship } \\
\text { Training Programme } \\
\text { (ATP) }\end{array}$ & Employment & 2000 & $\begin{array}{l}\text { Promote skills development of out-of-school } \\
\text { youth in order to mitigate youth unemployment } \\
\text { and ease the transition from school to workplace }\end{array}$ \\
\hline 2 & $\begin{array}{l}\text { Village Skills } \\
\text { Development } \\
\text { Programme Employment }\end{array}$ & 1996 & $\begin{array}{l}\text { Provide rural communities with needs-based } \\
\text { skills training to promote income and off-farm } \\
\text { employment generation prospects }\end{array}$ \\
\hline 3 & $\begin{array}{l}\text { Youth Development } \\
\text { Fund's (YDF's) } \\
\text { Carpentry Skills } \\
\text { Training Programme } \\
\text { for Out-of-School } \\
\text { Youth in Zhemgang }\end{array}$ & Employment & 2004 & $\begin{array}{l}\text { YDF an NGO initiated a Carpentry Skills Training } \\
\text { Programme for out-of-school youth in } \\
\text { Zhemgang. }\end{array}$ \\
\hline
\end{tabular}

3.1.3pws Of India:-India along with other Brazil, Malaysia, South Africa and China emerged as one of the developing country. India is part of many reputed groups like and becoming an important asset for many world's leading corporations. It is evident from facts that India emerges as one of the largest population country among all SAARC members. So, for helping peoples of Indian terms of employment, job security and education, government came up with beneficial PWS. Table 3 PWS of India list out few PWS including their sector and key provision.

Table 3 PWS of India

\begin{tabular}{|l|l|l|l|l|}
\hline S. No & Scheme & Sector & $\begin{array}{l}\text { Year of } \\
\text { starting }\end{array}$ & Key Provisions \\
\hline 1. & $\begin{array}{l}\text { Swarna Jayanti } \\
\text { Gram } \\
\text { SwarojgarYojana } \\
\text { (SGSY) }\end{array}$ & Employment & 1999 & $\begin{array}{l}\text { Self-employment programme to poor } \\
\text { families }\end{array}$ \\
\hline 2. & $\begin{array}{l}\text { Aajeevika- } \\
\text { National Rural } \\
\text { Livelihood } \\
\text { Mission(NRLM) }\end{array}$ & Employment & 2011 & $\begin{array}{l}\text { Promoting self-employment and } \\
\text { organization of rural poor }\end{array}$ \\
\hline 3. & $\begin{array}{l}\text { Mahatma Gandhi } \\
\text { National Rural } \\
\text { Employment } \\
\text { Guarantee Act } \\
\text { (MGNREGA) }\end{array}$ & Employment & 2005 & Rural households seeking manual work \\
\hline
\end{tabular}




\begin{tabular}{|l|l|l|l|l|}
\hline 4. & $\begin{array}{l}\text { Rashtriya Swasthya } \\
\text { Bima Yojana } \\
\text { (RSBY) }\end{array}$ & Health & Provide health insurance for BPL \\
families
\end{tabular}

3.1.4 PWS of Nepal: - Nepal is a small landlocked country in the central Himalayas which is surrounded between two large countries of the third world called India and China. Nepal's interest is finest served through regional economic cooperation. The Nepalese economy is working under several limitations like landlocked location; border connected with India and China, poor infrastructure facilities in transport and communication, dependency on foreign aid, small domestic market and skilled or unskilled labor forces etc. There are some public welfare schemes are launch for public welfare out of which some are discussed in Table 4 PWS of Nepal.

\section{Table 4 PWS of Nepal}

\begin{tabular}{|c|c|c|c|c|}
\hline S.No. & Scheme & Sector & $\begin{array}{l}\text { Year of } \\
\text { starting }\end{array}$ & Key Provisions \\
\hline 1. & $\begin{array}{l}\text { Rural Community } \\
\text { Infrastructure Works } \\
\text { (RCIW) }\end{array}$ & Employment & 1996- & $\begin{array}{l}\text { short-term consumption smoothing to } \\
\text { address food security }\end{array}$ \\
\hline 2. & $\begin{array}{l}\text { Rural Access } \\
\text { Programme } \\
\text { RAP } 1 \text { initiated } 2000 \\
\text { RAP } 2 \text { (2009-2013) } \\
\text { RAP } 3 \text { (2013-2017) }\end{array}$ & Employment & $2000-17$ & $\begin{array}{l}\text { Employment-entensive } \quad \text { Infrastructure } \\
\text { Programme (EIIP) - includes Public Works } \\
\text { Programme (PWP) for short-term } \\
\text { consumption smoothing to address poverty }\end{array}$ \\
\hline 3. & $\begin{array}{l}\text { Poverty Alleviation } \\
\text { Fund (PAF) }\end{array}$ & Employment & 2004- & $\begin{array}{l}\text { EIIP - includes PWP for short-term } \\
\text { consumption smoothing to address food } \\
\text { security }\end{array}$ \\
\hline 4. & $\begin{array}{l}\text { Karnali Employment } \\
\text { Programme } \\
\text { (KEP) }\end{array}$ & Employment & 2006- & $\begin{array}{l}\text { Employment Guarantee Scheme (EGS) } \\
\text { Objective: income insurance; reality: short- } \\
\text { term consumption smoothing }\end{array}$ \\
\hline 5. & $\begin{array}{l}\text { District Roads } \\
\text { Support Programme } \\
\text { (DRSP) }\end{array}$ & Employment & $\begin{array}{l}(1999- \\
2013)\end{array}$ & EIIP \\
\hline 6. & $\begin{array}{l}\text { Decentralized Rural } \\
\text { Infrastructure } \\
\text { Livelihood } \\
\text { Programme (DRILP) }\end{array}$ & Employment & $\begin{array}{l}\text { (Phase 2: } \\
\text { 2012- } \\
\text { 2016) }\end{array}$ & EIIP \\
\hline 7 & $\begin{array}{l}\text { Rural Reconstruction } \\
\text { Rehabilitation Sector }\end{array}$ & Employment & 2013 & EIIP \\
\hline
\end{tabular}




\begin{tabular}{|l|l|l|l|l|}
\hline & $\begin{array}{l}\text { Development Project } \\
\text { (RRRSDP) }\end{array}$ & & \\
\hline 8. & $\begin{array}{l}\text { Rural Access } \\
\text { Improvement and } \\
\text { Decentralization } \\
\text { Project (RAIDP) }\end{array}$ & & Employment & (ends \\
\hline
\end{tabular}

3.1.5 PWS Of Pakistan: -The area of Pakistan has a long history of settlement and civilization that includes some of the most ancient cultures. There are some public welfare schemes are launch for public welfare out of which some are discussed in Table 5 PWS of Pakistan.

Table 5 PWS of Pakistan

\begin{tabular}{|l|l|l|l|l|}
\hline S.No. & Scheme & Sector & $\begin{array}{l}\text { Year of } \\
\text { Starting }\end{array}$ & Key Provisions \\
\hline 1. & $\begin{array}{l}\text { Social } \\
\text { Empowerment }\end{array}$ & $\begin{array}{l}\text { Social } \\
\text { Protection }\end{array}$ & 1970 & $\begin{array}{l}\text { Women Centers has been established at } \\
\text { place where temporary shelter, free legal } \\
\text { aid, medical relief and psycho-social } \\
\text { counseling services to women in distress are } \\
\text { provided. The Government has established } \\
25 \text { Women Centers }\end{array}$ \\
\hline 2. & $\begin{array}{l}\text { Lady } \\
\text { Porkers' }\end{array}$ & $\begin{array}{l}\text { Social } \\
\text { Protection }\end{array}$ & 1994 & $\begin{array}{l}\text { To provide universal health coverage to the } \\
\text { people of Pakistan. }\end{array}$ \\
\hline Development & $\begin{array}{l}\text { Social } \\
\text { (Medical) Projects }\end{array}$ & $\begin{array}{l}\text { Community } \\
\text { Developmen } \\
\text { t }\end{array}$ & 2003 & $\begin{array}{l}\text { Eleven community development projects } \\
\text { are providing community based vocational } \\
\text { training, especially in the field of knitting, } \\
\text { embroidery and related skills to females and } \\
\text { radio/television repairing at village Noon } \\
\text { Islamabad, Ghanche, A store and District } \\
\text { Ghizer in Northern Areas, Kurram Agency, } \\
\text { Khyber Agency, South North Waziristan, } \\
\text { South Wazirstan Agency and Bajour Agency }\end{array}$ \\
\hline & $\begin{array}{l}\text { Economic } \\
\text { Empowerment }\end{array}$ & Economic & 2015 & $\begin{array}{l}\text { Concerted efforts are being made by the } \\
\text { Government to alleviate poverty amongst } \\
\text { the women of Pakistan. Consequently, the } \\
\text { Ministry of Women Development in } \\
\text { collaboration with development partners }\end{array}$ \\
\hline
\end{tabular}




\begin{tabular}{|l|l|l|l|l|}
\hline & & & $\begin{array}{l}\text { and financial institutions like Aga Khan } \\
\text { Rural Support Program (AKRSP) }\end{array}$ \\
\hline
\end{tabular}

3.1.5 Pws Of Sri Lanka: -In Sri lanka high unemployment rates and macro-economic imbalances have been significant problems in Sri Lanka since mid 1960s. There was a transition from a land-surplus economy in need of immigrant labour to develop her tea and rubber plantations, to a labour-surplus economy. Unemployment rates rose from about 10 to 11 percent of the labour force during the 1950s to a record high of 24 percent in the 1970's. The GDP Growth Rates were at a record low level and private foreign investment fell to a negligible level as result of economic policies adopted under the state-controlled economy. The overall effect was a virtual collapse of the economy in the mid-1970. There are some public welfare schemes are launch for public welfare out of which some are discussed in Table 6 PWS of Sri lanka.

\section{Table 6 PWS of Sri Lanka}

\begin{tabular}{|l|l|l|l|l|}
\hline S.No. & Scheme & Sector & $\begin{array}{l}\text { Year of } \\
\text { Starting }\end{array}$ & Key Provisions \\
\hline 1. & Mahinda Chinthana & $\begin{array}{l}\text { Economic } \\
\text { developmen } \\
\mathrm{t} \text { including } \\
\text { employment }\end{array}$ & $2006-16$ & $\begin{array}{l}\text { It is the foundation for most development } \\
\text { work in Sri Lanka. }\end{array}$ \\
\hline
\end{tabular}

\section{The Swot Analysis}

SWOT analysis is generally stands for Strengths, Weaknesses, Opportunities, and Threats. It is a basically a business analysis technique which helps in identifying organization's potential strengths and using them will help in creating opportunities and reducing threats; and identifying weaknesses in order to fade them. SWOT analysis helps to evaluate the present situation, and to identify measures. Inspire of benefits there are few drawbacks of this analysis like it depends on subjective instincts, avoids quantification, and lacks prognostic powers (Agarwal, et al., 2012). SWOT analysis is generally based on the individual's intuitions, which may change according to persons, which make effectiveness of SWOT analysis weak.

Before applying the SWOT to SAARC countries, it would appropriate to show the reasons for taking the SAARC countries for analysis. Afghanistan, Bangladesh, Bhutan, India, Maldives, Nepal, Pakistan, Sri Lanka are largest emerging market economies these countries have potential to grow faster than the developed countries. After getting the information about PWS of SAARC with the help of SWOT analysis strength, weakness, opportunities and threats are explained. Table 6discusses the SWOT analysis of SAARC various PWS.

\subsection{SWOT analysis of SAARC PWS: -}

Table 7 SWOT analysis of SAARC PWS

\begin{tabular}{|c|c|c|c|c|c|c|}
\hline $\begin{array}{l}\text { S.N } \\
\text { o. }\end{array}$ & Nation & Programme & Strengths & Weakness & $\begin{array}{l}\text { Opportuniti } \\
\text { es }\end{array}$ & Threats \\
\hline 1. & $\begin{array}{l}\text { Banglade } \\
\text { sh }\end{array}$ & $\begin{array}{l}\text { Food-For- } \\
\text { Work (FFWP) } \\
\text { programme }\end{array}$ & $\begin{array}{l}\text { 1. It is a wide } \\
\text { programme } \\
\text { incorporating many } \\
\text { governmental } \\
\text { departments and } \\
\text { ministries, displays }\end{array}$ & $\begin{array}{l}\text { 1. Expenditure } \\
\text { oriented and not } \\
\text { demand driven. } \\
\text { 2. Poor record } \\
\text { maintenance }\end{array}$ & $\begin{array}{l}\text { 1. Scheme } \\
\text { can be } \\
\text { redesigned } \\
\text { to match skill } \\
\text { sets. }\end{array}$ & $\begin{array}{lr}\text { 1. } & \text { Corruption } \\
\& & \\
\text { irregularities. } \\
2 . & \text { Rural } \\
2 . & \text { people } \quad \text { are }\end{array}$ \\
\hline
\end{tabular}


ISSN: 2321-1091

Volume: 12 Issue: 01

Journal of Social Science Research

\begin{tabular}{|c|c|c|c|c|c|c|}
\hline & & & $\begin{array}{l}\text { a fine } \\
\text { administrative } \\
\text { coordination. } \\
\text { 2.It is capable in } \\
\text { generating a } \\
\text { seasonal } \\
\text { employment trend } \\
\text { in Bangladesh } \\
\text { economy. }\end{array}$ & $\begin{array}{l}\text { and work } \\
\text { measurement. } \\
\text { 3. Increment in } \\
\text { number of } \\
\text { lethargic labour. }\end{array}$ & $\begin{array}{l}\text { 2. Linkage to } \\
\text { other } \\
\text { schemes. }\end{array}$ & $\begin{array}{l}\text { being } \\
\text { dependent on } \\
\text { the scheme in } \\
\text { spite of self } \\
\text { reliant. } \\
\text { 3. Need to } \\
\text { consider the } \\
\text { benefits of } \\
\text { converge with } \\
\text { other Acts. }\end{array}$ \\
\hline & & $\begin{array}{l}\text { Rural } \\
\text { Maintenance } \\
\text { Programme } \\
\text { (RMP) }\end{array}$ & 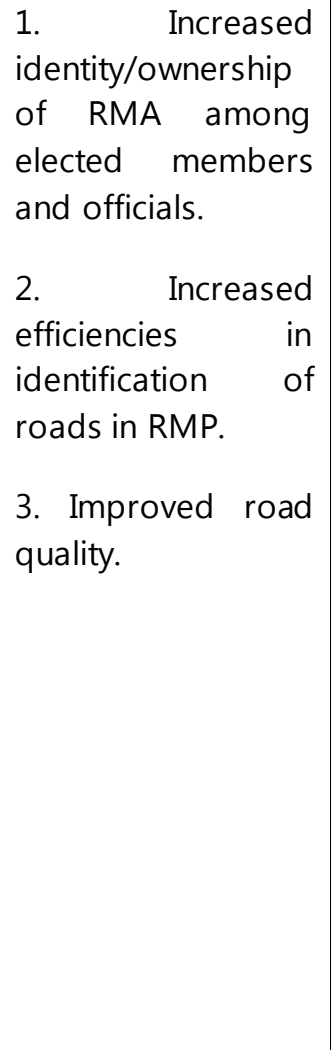 & $\begin{array}{l}\text { 1. Persistence of } \\
\text { socially } \\
\text { constructed } \\
\text { gender roles. } \\
2 . \quad \text { Inter- } \\
\text { Ministerial } \\
\text { coordination } \\
\text { affecting RMP } \\
\text { Cell. } \\
\text { 3. } \\
\text { preparation of } \\
\text { alternative } \\
\text { training } \\
\text { sources/instituti } \\
\text { ons to sustain } \\
\text { CS. }\end{array}$ & $\begin{array}{l}\text { 1. Public } \\
\text { support for } \\
\text { RMP. } \\
\text { 2. Excellent } \\
\text { combination } \\
\text { of social and } \\
\text { economic } \\
\text { benefits } \\
\text { through } \\
\text { RMP. } \\
\text { 3. Trained } \\
\text { cadre of RMA } \\
\text { members, UP } \\
\text { secretaries, } \\
\text { local } \\
\text { residents and } \\
\text { elected } \\
\text { members } \\
\text { creating a } \\
\text { favorable } \\
\text { environment. }\end{array}$ & $\begin{array}{l}\text { 1. Ambiguity } \\
\text { about the } \\
\text { future of RMP } \\
\text { itself. } \\
\text { 2. Financial } \\
\text { resource } \\
\text { constraints at } \\
\text { both Upazilas } \\
\text { and Ups. } \\
\text { 3. Male } \\
\text { dominance in } \\
\text { Upazilas and } \\
\text { Ups. }\end{array}$ \\
\hline & & $\begin{array}{l}\text { 100-Day } \\
\text { Employment } \\
\text { Generation } \\
\text { Programme } \\
\text { (100-EGP) }\end{array}$ & $\begin{array}{l}\text { 1.It was the largest } \\
\text { safety net } \\
\text { programme in the } \\
\text { history of the GOB } \\
\text { that focused on } \\
\text { employment } \\
\text { generation. } \\
2 . \quad \text { Women } \\
\text { benefited in terms } \\
\text { of food security. }\end{array}$ & $\begin{array}{l}\text { 1. Bias in the } \\
\text { beneficiary } \\
\text { selection. } \\
\text { 2. Lack of } \\
\text { adequate } \\
\text { preparation to } \\
\text { implement the } \\
\text { programme. } \\
\text { 3. In most cases } \\
\text { actual working }\end{array}$ & $\begin{array}{l}\text { 1. GoB } \\
\text { should take } \\
\text { long-term } \\
\text { programme } \\
\text { so that the } \\
\text { problems of } \\
\text { poor people } \\
\text { are solved } \\
\text { permanently. }\end{array}$ & $\begin{array}{l}1 . \quad \text { Low } \\
\text { outreach of } \\
\text { extreme poor } \\
\text { people. } \\
2 . \quad \text { Ad hoc } \\
\text { work } \\
\text { selection } \\
\text { rather than } \\
\text { integrated } \\
\text { plan with the } \\
\text { local }\end{array}$ \\
\hline
\end{tabular}


ISSN: 2321-1091

Volume: 12 Issue: 01

Journal of Social Science Research

\begin{tabular}{|c|c|c|c|c|c|c|}
\hline & & & $\begin{array}{l}\text { 3. It furnished } \\
\text { positive effects on } \\
\text { the long-term } \\
\text { investment in } \\
\text { productive assets. }\end{array}$ & $\begin{array}{l}\text { days do not } \\
\text { match with } \\
\text { official records. }\end{array}$ & & $\begin{array}{l}\text { development } \\
\text { planning. } \\
\text { 3.Lack of } \\
\text { proper } \\
\text { monitoring, } \\
\text { and } \\
\text { corruption in } \\
\text { payments } \\
\text { system. }\end{array}$ \\
\hline 2. & Bhutan & $\begin{array}{l}\text { Apprenticesh } \\
\text { ip Training } \\
\text { Programme } \\
\text { (ATP) }\end{array}$ & $\begin{array}{l}\text { 1.It is a non-formal } \\
\text { programme to } \\
\text { further promote } \\
\text { skills development } \\
\text { of out-of-school } \\
\text { youth in order to } \\
\text { mitigate youth } \\
\text { unemployment and } \\
\text { ease the transition } \\
\text { from school to } \\
\text { workplace. } \\
\text { 2.It was expected } \\
\text { to reduce the } \\
\text { shortage of skilled } \\
\text { workers in the } \\
\text { private sector, } \\
\text { particularly in } \\
\text { occupations for } \\
\text { which no training } \\
\text { mechanisms exist. } \\
\text { 3. An additional } \\
\text { objective was to } \\
\text { promote a wider } \\
\text { acceptance of such } \\
\text { occupations. } \\
\text { 4. An impact } \\
\text { assessment } \\
\text { analysis found the } \\
\text { programme is } \\
\text { effective, relevant } \\
\text { and cost-effective. }\end{array}$ & & $\begin{array}{l}\text { 1. An impact } \\
\text { assessment } \\
\text { analysis } \\
\text { Recommend } \\
\text { ed it should } \\
\text { be expanded } \\
\text { to include a } \\
\text { greater } \\
\text { number of } \\
\text { apprentices } \\
\text { and an } \\
\text { increased } \\
\text { number of } \\
\text { trades. } \\
\text { 2. To achieve } \\
\text { planned } \\
\text { targets and } \\
\text { to have a } \\
\text { more } \\
\text { meaningful } \\
\text { impact on } \\
\text { alleviating } \\
\text { youth } \\
\text { unemployme } \\
\text { nt, the } \\
\text { programme } \\
\text { intake must } \\
\text { be expanded } \\
\text { significantly. }\end{array}$ & $\begin{array}{l}\text { 1. Impact } \\
\text { assessment } \\
\text { analysis } \\
\text { highlighted } \\
\text { the need to } \\
\text { improve } \\
\text { some aspects } \\
\text { of the } \\
\text { programme } \\
\text { and (i) } \\
\text { raised certain } \\
\text { issues: than } \\
\text { More tha } \\
\text { half of those } \\
\text { trained under } \\
\text { the ATP were } \\
\text { employed, } \\
\text { but no } \\
\text { Information } \\
\text { was available } \\
\text { on the others. } \\
\text { (ii) The need } \\
\text { to maintain } \\
\text { proper } \\
\text { Documentati } \\
\text { on and } \\
\text { records of } \\
\text { apprentices } \\
\text { and improve } \\
\text { the selection } \\
\text { process. } \\
\text { (iii) The study } \\
\text { further } \\
\text { stressed the }\end{array}$ \\
\hline
\end{tabular}


ISSN: 2321-1091

Volume: 12 Issue: 01

Journal of Social Science Research

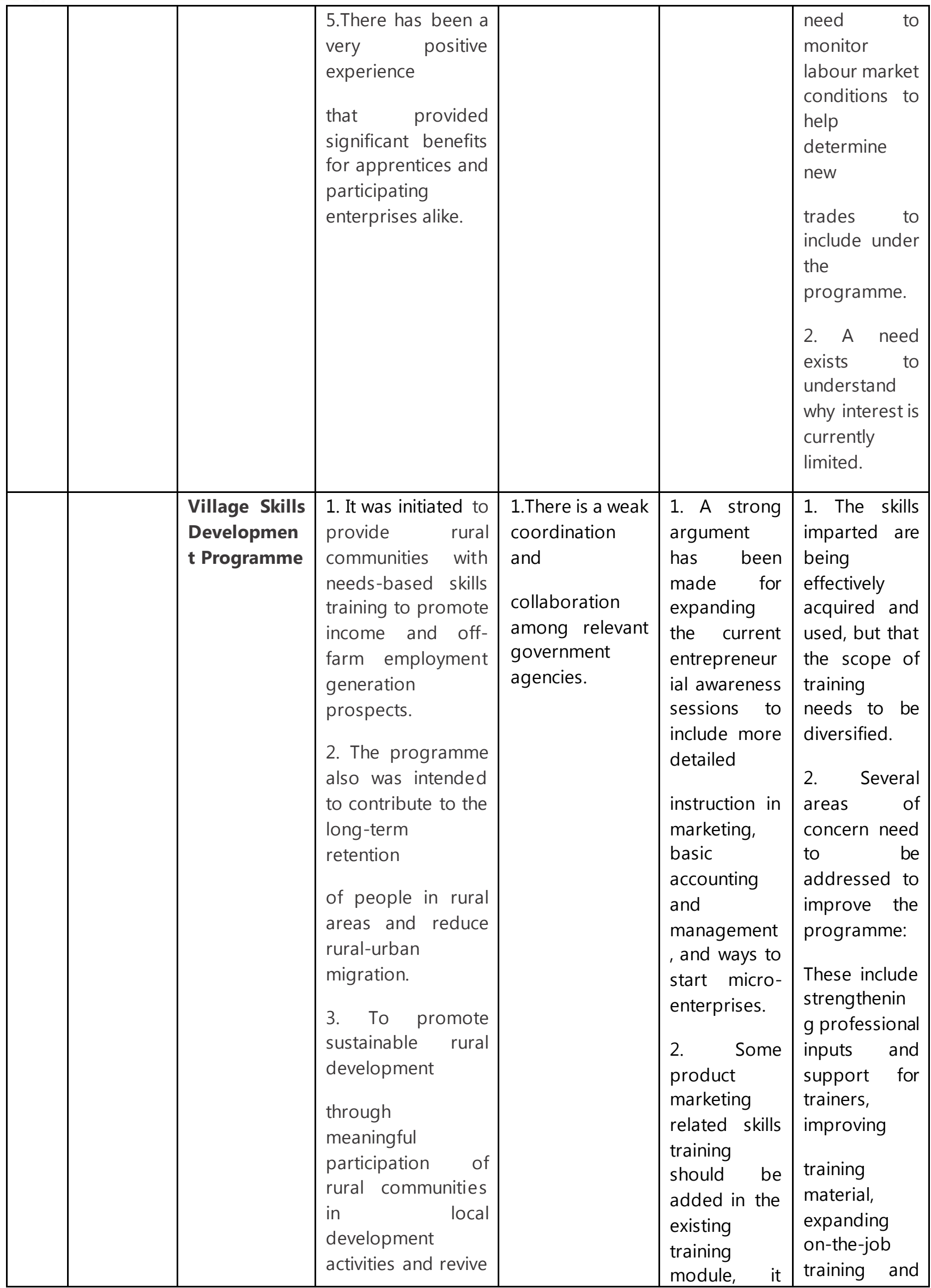


ISSN: 2321-1091

Volume: 12 Issue: 01

Journal of Social Science Research

\begin{tabular}{|c|c|c|c|c|c|c|}
\hline & & & $\begin{array}{l}\text { and preserve } \\
\text { traditional arts and } \\
\text { crafts. } \\
\text { 4. While } \\
\text { participation was } \\
\text { open to all, the } \\
\text { programme sought } \\
\text { to target school } \\
\text { dropouts, } \\
\text { unschooled } \\
\text { individuals, women } \\
\text { and the poor. } \\
\text { 5. Notwithstanding } \\
\text { resource } \\
\text { constraints, the } \\
\text { programme is seen } \\
\text { to be cost-effective } \\
\text { and clearly feasible. } \\
6 . \text { Strongly } \\
\text { supported by the } \\
\text { community. }\end{array}$ & & $\begin{array}{l}\text { would } \\
\text { enhance the } \\
\text { employment } \\
\text { opportunitie } \\
\text { s. } \\
\text { 3.It is } \\
\text { imperative to } \\
\text { enhance } \\
\text { market } \\
\text { access for } \\
\text { village } \\
\text { products and } \\
\text { produce, } \\
\text { given that } \\
\text { this will } \\
\text { fundamentall } \\
\text { y determine } \\
\text { the } \\
\text { sustainability } \\
\text { of farm } \\
\text { and off-farm } \\
\text { activities. }\end{array}$ & $\begin{array}{l}\text { training-cum- } \\
\text { production } \\
\text { and } \\
\text { incorporating } \\
\text { post-training } \\
\text { follow-ups } \\
\text { consistently. } \\
\text { 3.There is a } \\
\text { major need } \\
\text { for proper } \\
\text { market } \\
\text { surveys and } \\
\text { relevant } \\
\text { research, } \\
\text { which can } \\
\text { effectively } \\
\text { help, identify } \\
\text { and link } \\
\text { village } \\
\text { production } \\
\text { and skills } \\
\text { training to } \\
\text { real market } \\
\text { demands. }\end{array}$ \\
\hline 3. & India & $\begin{array}{l}\text { Swaranjayan } \\
\text { ti Gram } \\
\text { Swarozgar } \\
\text { Yojana } \\
\text { (SGSY) }\end{array}$ & 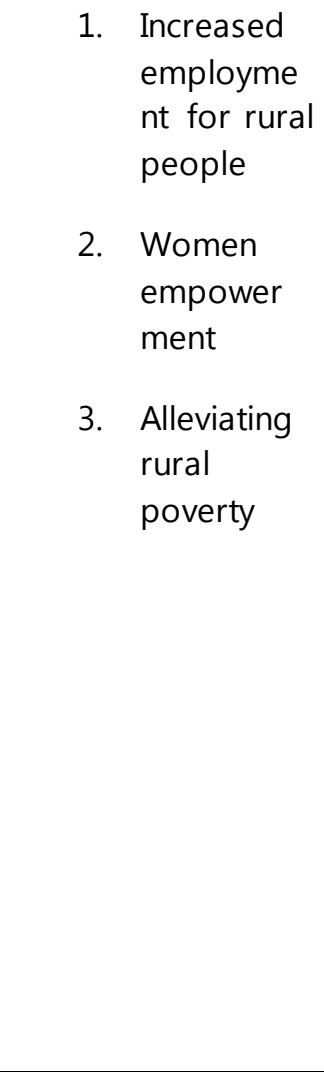 & $\begin{array}{l}\text { 1. Little attention } \\
\text { is paid towards } \\
\text { facilitating } \\
\text { processes } \\
\text { 2. Less } \\
\text { institutional } \\
\text { capacity } \\
\text { 3. Knowledge } \\
\text { about the } \\
\text { scheme is not } \\
\text { known and } \\
\text { understood by } \\
\text { majority of the } \\
\text { members } \\
4 \text {. The interest } \\
\text { rate charged is } \\
\text { very high for BPL } \\
\text { category } \\
5 \text { monitoring of } \\
\text { moor }\end{array}$ & $\begin{array}{l}\text { 1.For } \\
\text { manage the } \\
\text { economic } \\
\text { activity hire } \\
\text { literate staff. } \\
\text { 2. The banks } \\
\text { should } \\
\text { provide loan } \\
\text { to majority } \\
\text { members } \\
\text { without } \\
\text { trouble } \\
\text { 3. Monitoring } \\
\text { the } \\
\text { performance } \\
\text { of the } \\
\text { scheme on } \\
\text { regular basis. } \\
4 \text { Proper } \\
\text { training } \\
\text { programmes }\end{array}$ & $\begin{array}{l}\text { 1. There is } \\
\text { nodelinkof } \\
\text { facility of } \\
\text { capital } \\
\text { subsidy. } \\
\text { 2. Less } \\
\text { awareness } \\
\text { about the } \\
\text { scheme. } \\
\text { 3. } \\
\text { enhancing in } \\
\text { the loan } \\
\text { amount from } \\
\text { time to time. } \\
\text { 5. Corruption } \\
\& \text { irregularities. }\end{array}$ \\
\hline
\end{tabular}




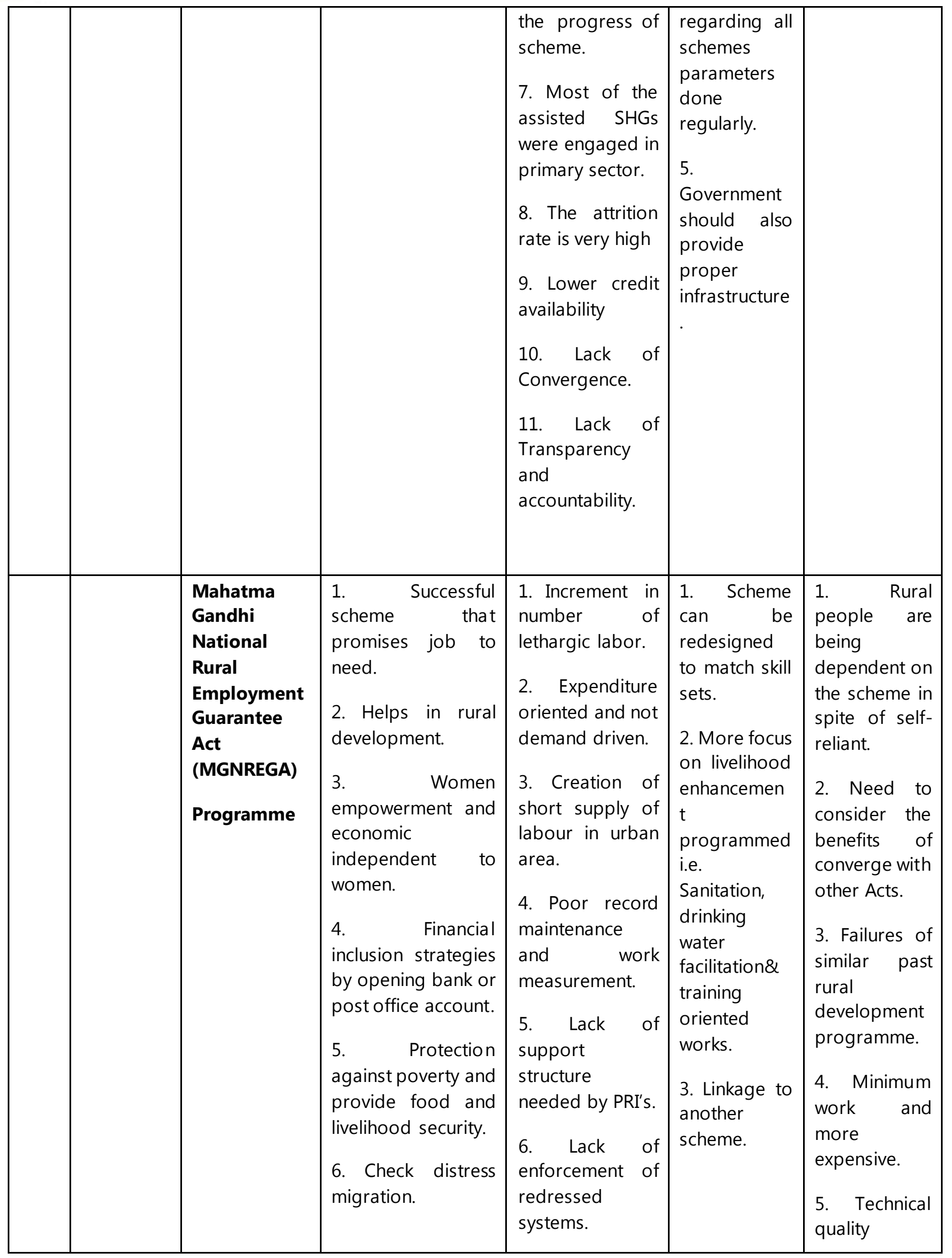


ISSN: 2321-1091

Volume: 12 Issue: 01

Journal of Social Science Research

\begin{tabular}{|c|c|c|c|c|c|c|}
\hline & & & & & & $\begin{array}{l}\text { management } \\
\text { failures. } \\
6 . \quad \text { No } \\
\text { differentiatio } \\
\mathrm{n} \text { between } \\
\text { educated and } \\
\text { skilled } \\
\text { people. } \\
\text { 7. Pilferage of } \\
\text { material from } \\
\text { sites.8. } \\
\text { Corruption\& } \\
\text { irregularities. } \\
\text { 9. Long time } \\
\text { gap between } \\
\text { planning of } \\
\text { works and } \\
\text { their } \\
\text { execution. }\end{array}$ \\
\hline & & $\begin{array}{l}\text { Aajeevika- } \\
\text { National } \\
\text { Rural } \\
\text { Livelihood } \\
\text { Mission(NRL } \\
\text { M) }\end{array}$ & $\begin{array}{l}\text { 1.Poverty reduction } \\
\text { 2. Institutional } \\
\text { platform for the } \\
\text { poor introduced } \\
\text { 3. Supports } \\
\text { enterprise } \\
\text { development in the } \\
\text { local service sector }\end{array}$ & & 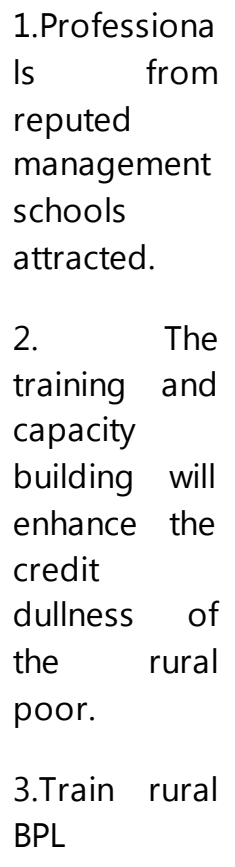 & $\begin{array}{l}\text { 1. Required } \\
\text { openness, } \\
\text { flexibility, } \\
\text { innovation } \\
\text { and learning. }\end{array}$ \\
\hline 4. & Nepal & $\begin{array}{l}\text { Karnali } \\
\text { Employment } \\
\text { Programme } \\
\text { (KEP) }\end{array}$ & $\begin{array}{l}\text { 1. Very successful } \\
\text { scheme that } \\
\text { promises job to } \\
\text { need. }\end{array}$ & $\begin{array}{l}\text { 1. Due to lack of } \\
\text { budget } \\
\text { allocated to the } \\
\mathrm{KEP} \text {, the public } \\
\text { objective of }\end{array}$ & $\begin{array}{l}\text { 1. Scheme } \\
\text { can be } \\
\text { redesigned } \\
\text { to match skill } \\
\text { sets. }\end{array}$ & $\begin{array}{l}\text { 1. There is } \\
\text { lack of } \\
\text { immediate } \\
\text { government } \\
\text { demand for }\end{array}$ \\
\hline
\end{tabular}


ISSN: 2321-1091

Volume: 12 Issue: 01

Journal of Social Science Research

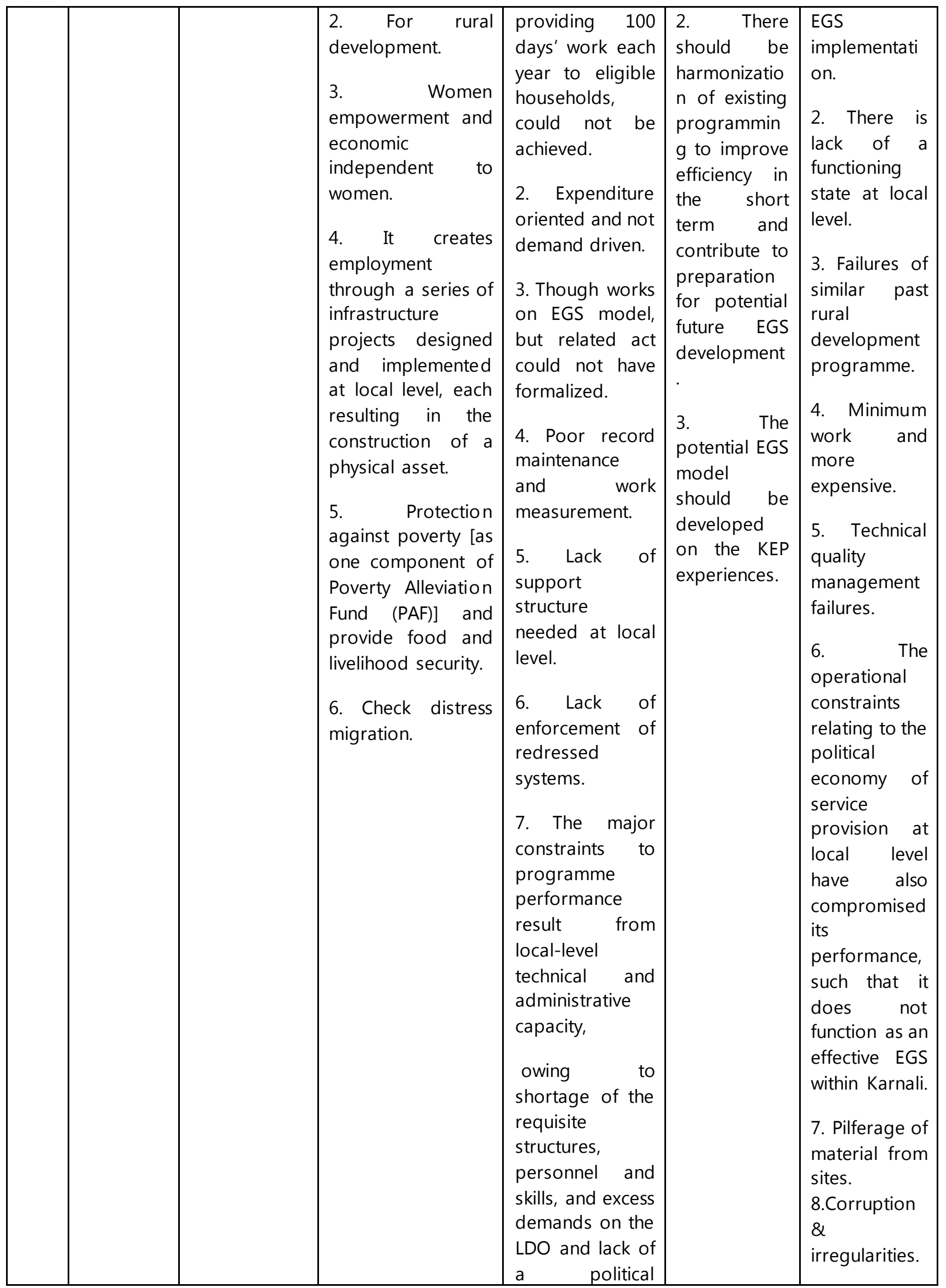


ISSN: 2321-1091

Volume: 12 Issue: 01

Journal of Social Science Research

\begin{tabular}{|c|c|c|c|c|c|c|}
\hline & & & & $\begin{array}{l}\text { preference or } \\
\text { requirement to } \\
\text { priorities those } \\
\text { resources that } \\
\text { are available to } \\
\text { the KEP over } \\
\text { other } \\
\text { programmes. } \\
\text { 8. Due to lack of } \\
\text { requisite } \\
\text { institutions and } \\
\text { technical } \\
\text { capacity wages } \\
\text { being paid to } \\
\text { participants } \\
\text { without } \\
\text { realization of the } \\
\text { work for } \\
\text { requirement. } \\
\text { 9. Leakage of } \\
\text { funds and } \\
\text { fiduciary risk. } \\
\text { 10. Poor asset } \\
\text { quality. } \\
\text { 11. It has been } \\
\text { criticized for } \\
\text { having achieved } \\
\text { little in terms of } \\
\text { assets created or } \\
\text { being very costly } \\
\text { for the output. }\end{array}$ & & $\begin{array}{l}\text { 9. Long time } \\
\text { gap between } \\
\text { planning of } \\
\text { works and } \\
\text { their } \\
\text { execution. }\end{array}$ \\
\hline 5. & Pakistan & $\begin{array}{l}\text { Lady Health } \\
\text { Workers' } \\
\text { Programme }\end{array}$ & $\begin{array}{l}\text { 1. Political } \\
\text { commitment. } \\
\text { 2. Recruitment and } \\
\text { Selection } \\
\text { procedures. } \\
\text { 3. Wide coverage } \\
\text { outreach - rural } \\
\text { areas focused. }\end{array}$ & $\begin{array}{l}\text { 1. Poor } \\
\text { management at } \\
\text { lower level. } \\
\text { 2. Poor } \\
\text { integration at } \\
\text { lower levels. } \\
\text { 3. Problems in } \\
\text { salaries } \\
\text { payment. }\end{array}$ & $\begin{array}{l}\text { 1. Wide } \\
\text { coverage and } \\
\text { social } \\
\text { acceptability. } \\
\text { 2. Training } \\
\text { capacity can } \\
\text { be used by } \\
\text { others. } \\
\text { 3. Emergency } \\
\text { obstetrical } \\
\text { care training }\end{array}$ & $\begin{array}{l}\text { 1. Poverty, } \\
\text { patriarchy } \\
\text { and social } \\
\text { norms. } \\
\text { 2. Political } \\
\text { interference. } \\
\text { 3. Lack of } \\
\text { funds. }\end{array}$ \\
\hline
\end{tabular}


ISSN: 2321-1091

Volume: 12 Issue: 01

Journal of Social Science Research

\begin{tabular}{|c|c|c|c|c|c|c|}
\hline & & & $\begin{array}{l}\text { 4. Integrations with } \\
\text { healthcare system } \\
\text { at upper levels. } \\
\text { 5. Defined } \\
\text { management and } \\
\text { supervisory } \\
\text { structures. } \\
\text { 6. Comprehensive } \\
\text { healthcare } \\
\text { provision. } \\
\text { 7. Management } \\
\text { Information System } \\
\text { (MIS). } \\
\text { 8. Training of LHWs } \\
\text { part of the system. } \\
9 . \text { Positive impact } \\
\text { on health } \\
\text { indicators. } \\
\text { 10. Cost effective } \\
\text { intervention. }\end{array}$ & 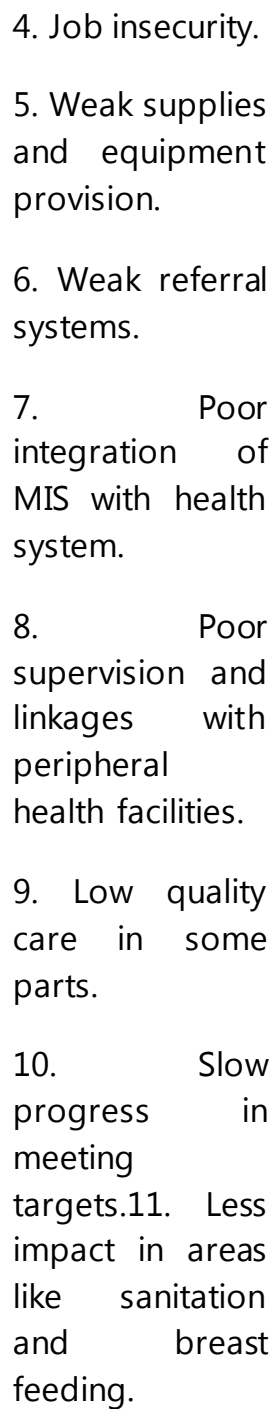 & $\begin{array}{l}\text { for some } \\
\text { LHWs. } \\
\text { 4. Health } \\
\text { system } \\
\text { research. } \\
\text { 5. Use for } \\
\text { women } \\
\text { empowerme } \\
\text { nt. } \\
\text { 6. Use for } \\
\text { poverty } \\
\text { alleviation } \\
\text { strategies. }\end{array}$ & $\begin{array}{l}\begin{array}{l}4 . \quad \text { Political } \\
\text { and social } \\
\text { environment. }\end{array} \\
5 . \quad \text { Non- } \\
\text { acceptance } \\
\text { by } \\
\text { established } \\
\text { medical } \\
\text { professions. } \\
6 . \quad \text { Quackery } \\
\text { implications. }\end{array}$ \\
\hline 6. & $\begin{array}{l}\text { Shri } \\
\text { Lanka }\end{array}$ & $\begin{array}{l}\text { Mahinda } \\
\text { Chinhana }\end{array}$ & $\begin{array}{l}\text { 1. It is the } \\
\text { foundation for } \\
\text { most development } \\
\text { work in Sri Lanka. } \\
\text { 2. It aims to reduce } \\
\text { youth (15-24) } \\
\text { unemployment by } \\
\text { generating gainful } \\
\text { employments } \\
\text { through } \\
\text { private, public and } \\
\text { foreign job } \\
\text { opportunities. }\end{array}$ & & $\begin{array}{l}\text { 1. Monitoring } \\
\text { and } \\
\text { evaluation of } \\
\text { outcomes to } \\
\text { guide future } \\
\text { policies and } \\
\text { initiatives. } \\
2 \quad \text { It is } \\
\text { imperative to } \\
\text { include } \\
\text { generic and } \\
\text { soft skills on } \\
\text { the agenda. } \\
\text { 3. It is } \\
\text { necessary to } \\
\text { create } \\
\text { standardized }\end{array}$ & 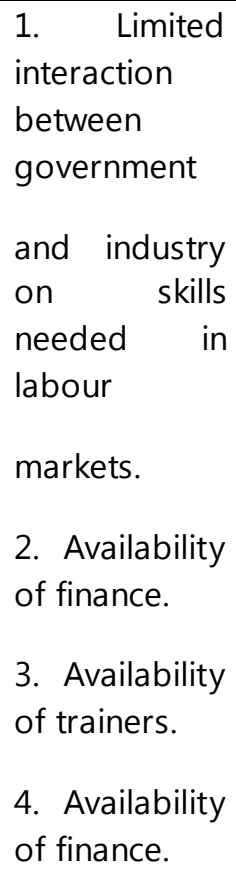 \\
\hline
\end{tabular}




\begin{tabular}{|l|l|l|l|l|l|}
\hline & & & & $\begin{array}{l}\text { quality- } \\
\text { control and } \\
\text { accreditation } \\
\text { systems. }\end{array}$ & $\begin{array}{l}5 . \text { Dated } \\
\text { training } \\
\text { models and } \\
\text { curricula. }\end{array}$ \\
\hline
\end{tabular}

\section{Discussion And Conclusion}

It is evident from literature that many authors committed that PWS are very useful in welfare of peoples. Hence, it is necessary for government to understand and to evaluate ongoing and past PWS benefits, weakness and future avenues so that they must know where to put more focus and resources. In this paper an attempt is made to collect prevalent data pertaining to SAARC PWS and with the help of SWOT analysis all parameters regarding PWS are studied like strength, weakness, opportunities and threats and compared so that one can understand global projection of PWS. From the SWOT analysis table it is seen that South African PWS named Expanded Public Works Programme (EPWP) have Low quality training for participants, only focus on existing road infrastructure, so the programme remained the story of "unfinished rural transformation and revolution". Similarly, on the other hand the new Russian pension scheme made Russian workers and pensioners more secure about their post-retirement futures than they were under the prior scheme (1999s), reducing nation's fiscal burden but is less advantageous for workers in the informal sector. China's PWS named Yigong-daizhen programme provided Farmers and administrative cadres training in their fields, but unskilled workers exploited individually due to unpaid work but benefitted collectively by improved rural infrastructure. Indian PWS Swarnajayanti Gram Swarojgar Yojna (SGSY) becomes the Indian largest holistic programme covering all aspects of self-employment for rural BPL people based on micro finance concepts but the prescribed guidelines were not followed properly and in practice activities are focused on low productivity primary sector. Lastly brazil PWS Bolsa Familia Programme (BFP) becomes the scheme to reduce poverty, and even reduce inter-generational transmission of poverty, but became controversial in Brazil under presumption that people with less education would not use their money wisely. Hence from above analysis it is seen that those who are considering selfemployment require an understanding of what will be involved, including the assessment of risk and of the costs (and benefits) of working for oneself. Attitudes, values and behaviors may also be important in forming entrepreneurial intentions. At pre-entry stage, business planning, including market research is important. Such a planning process will be supported by generic management skills. The quality of the business idea itse If is also of clear significance. For entry and survival, a variety of capabilities are necessary, including the capacity to deal with the practicalities of finance, legislation, business development and sales. Management skills (including many strategic functions) and financial capabilities have been identified as being particularly crucial, and deficiencies in this area may cause failure. Growth and expansion require refinements in management skills, especially with regard to human resource management. On the basis of empirical results, the new activities based on local resources, occupational skills of the people and availability of markets for rural entrepreneurship would be identified and an appropriate skill development framework would be formulated. The design, duration of training and the training curriculum would be tailored to meet the needs of the identified key activities.

\section{References}

1. Achieving Excellence (2002): Achieving Excellence: Investing in People, Knowledge and Opportunity: Ottawa: Government of Canada, Canada's Innovation Strategy, Industry Canada.

2. Agarwal, R., Grassl, W., and Pahl, J. (2012). Meta-SWOT: introducing a new strategic planning tool. Journal of Business Strategy, 33(2), pp. 12-21.

3. Akhter U. Ahmed, SajjadZohir, Shubh K. Kumar and Omar HaiderChowdhury, (2008), Bangladesh's food-for-work program and alternatives to improve food security. 
ISSN: 2321-1091

Volume: 12 Issue: 01

Journal of Social Science Research

4. Jane Andrews and Higson Helen (2008): Graduate Employability, 'Soft Skills' Versus 'Hard' Business Knowledge: A European Study. Higher Education in Europe, Vol. 33, No. 4, December 2008.

5. AyubArslan, RazzaqAdeel, Aslam Muhammad Salman and IftekharHanan (2013): A Conceptual Framework on Evaluating Swot Analysis as The Mediator in Strategic Marketing Planning Through Marketing Intelligence. European Journal of Business and Social Sciences, Vol. 2, No. 1, pp 91-98.

6. Badodiya S.K., M.M. Sadhana, Patel and Daipuria O.P. (2012): Impact of Swarna Jayanti Gram SwarozgarYojana on Poverty Alleviation. Indian Res. J. Ext. Edu. 12 (3), September, 2012.

7. Baker, R. L. (1991). The Social Work Dictionary. Silver Spring, National Association of Social Workers.

8. Cawson, A. (1982). Corporatism and Welfare. London, Heinemann. Devereux, S. and Solomon, C. (2006), \Employment Creation Programmes: The International Experience," ILO Issues in Employment and Poverty Discussion Paper No. 24.

9. Centre for Science and Environment (CSE) 2008, NREGA, Opportunities and Challenges, Centre for Science and Environment, New Delhi.

10. Chakrabarti, Saumya (2013): A Comparative Study of some of the Employment Guarantee Schemes across the Developing Countries. Working Paper Series: No. 2, 2012-2013.UGC SAP (DRS-I), Department of Economics and Politics, Visva-Bharati.

11. Deka Ajay Kumar, HazarikaPadmalochan (2013): Generation of Income of Rural Poor through Swarnajayanti Gram SwarozgarYojana (Sgsy) -A Study Relating to Kamrup District (Rural) of Assam. IJcaes special issue on Basic, Applied \& Social Sciences, Vol. III, January 2013.

12. Dev, S. (1995): India's (Maharashtra) employment guarantee scheme: Lessons from long experience. In von Braun J. (ed.). Employment for Poverty Reduction and Food Security. Washington, D.C.: International Food Policy Research Institute.

13. Dreze Jean and Khera, Reetika (2009): The battle for employment guarantee, Frontline, 26 (01), Jan. 03-16.

14. EPWP (2005) Expanded Public Works Programme (EPWP): Fourth Quarterly Report (1 April $2004-31$ March 2005), Pretoria: Department of Public Works.

15. Jane Andrews and Higson Helen (2008): Graduate Employability, 'Soft Skills' Versus 'Hard' Business Knowledge: A European Study. Higher Education in Europe, Vol. 33, No. 4, December 2008

16. Betcherman, Gordon, Karina Olivas, and Amit Dar. (2004): "Impact of Active Labor Market Programs: New Evidence from Evaluations with Particular Attention to Developing and transition Countries." Washington, D.C.: World Bank, Social Protection Discussion Paper Series 0402.

17. Dar, Amit and P. ZafirisTzannatos. (1999): "Active Labor Market Programs: A Review of the Evidence from Evaluations," Social Protection Discussion Paper no. 9901, January. The World Bank. Washington, D.C.

18. Dreze, Jean (2008): NREGA: ship without rudder? The Hindu, July, 2008.

19. Dugarova, E. (2016): The Family in a New Social Contract: The Case of Russia, KazakhstanandMongolia. UNRISD Research Paper. Geneva: UNRISD.

20. Dutt Polly (2009): Attaining Sustainable Rural Infrastructure through the National Rural Employment Guarantee Scheme in India. Commonwealth Journal of Local Governance Issue 4: November 2009.

21. Dreze, Jean (2011): “Employment Guarantee and the Right to Work”, in Khera, Ritika (ed.) (2011): The Battlerfor Employment Guarantee, New Delhi: Oxford, p.9. 
ISSN: 2321-1091

Volume: 12 Issue: 01

Journal of Social Science Research

22. Fretwell, D.H., J. Benus, and C.J. O'Leary (1999): “Evaluating the Impact of Active Labor Market Programs: Results of Cross Country Studies in Europe and Asia." Social Protection Discussion Paper No. 9915, Washington: The World Bank.

23. Gay, Robert, and Michael Borus (1980): "Validating performance indicators for employment and training programs," Journal of Human Resources. Winter 1980, 15, 29-48.

24. Godfrey, Martin (2003): "Youth Employment Policy in Developing and Transition CountriesPrevention as well as Cure" World Bank Social Protection Discussion Paper Series No. 0320, Washington D.C., World Bank.

25. Goldstein, I. L., Ford, K. (2002) Training in Organizations: Needs assessment, Development and Evaluation

26. Gordon Betcherman, Martin Godfrey, Susana Puerto, FriederikeRother, and Antoneta (2007): A Review of Interventions to Support Young Workers: Findings of the Youth. Employment Inventory. S P Discussion Paper, No. 0715, The World Bank, October 2007.

27. Greenberg, David H.; Charles Michalopoulos; Philip K. Robins (2003): "A Meta-Analysis of Government-Sponsored Training Programs". Industrial \& Labor Relations Review. Volume 57, Issue 1 2003 Article 2.

28. Heckman, J.J., R.J. LaLonde and J.A. Smith (1999): "The economics and econometrics of active labour market programs", in O. Ashenfelter and D. Card (eds.), Handbook of Labor Economics 3, Elsevier, Amsterdam.

29. H. O. Falola, A. O. Osibanjo, and S. I. Ojo (2014): "Effectiveness of Training and Development on Employees' Performance and Organization Competitiveness in the Nigerian Banking Industry". Bulletin of the TransilvaniaUniversity of Braşov Series V: Economic Sciences • Vol. 7 (56) No. 1 - 2014

30. International Finance Corporation and the World Bank (2006): Doing Business Database.

31. International Labor Office (2004): Global Employment Trends for Youth, Geneva, ILO.

32. International Labor Office (2005): Youth: Pathways to Decent Work, Background Report of the International Labor Conference, 93rd session, Geneva, ILO.

33. International Labor Office (2006): Global Employment Trends for Youth, Geneva, ILO.

34. Johanson, Richard K., and Arvil Van Adams (2004): Skills Development in Sub-Saharan

35. Africa. Washington, DC: World Bank.

36. Lal R., MillerS., Lieuw-Kie-Song M., Kostzer D.; PUBLIC WORKS AND EMPLOYMENT PROGRAMMES: TOWARDS A LONG-TERM DEVELOPMENT APPROACH, UNDP Poverty Group Working Paper number 66 June, 2010.

37. McCord, Anna (2004) 'Policy Expectations and Programme Reality: The Poverty Reduction and Labour Market Impact of Two Public Works Programmes in South Africa' ODI/ESAU Working paper 8

38. McCord, Anna (2005) 'Win-win or lose-lose? An Examination of the Use of Public Works as a Social Protection Instrument in Situations of Chronic Poverty' presented at the Conference on Social Protection for Chronic Poverty, Institute for Development Policy and Management University of Manchester, 23-24 Feb 2005.

39. McCord, Anna (2007) 'EPWP Mid Term Review: Component 1International PWP Comparative Study' SALDRU, University of Cape Town

40. McCord, Anna (2008) 'A typology for Public Works Programming' Natural Resource Perspectives \#121, December 2008 .

41. Mehrotra, Santosh (2008a) 'National Rural Employment Guarantee Act 2005,' presentation at the Citizen City International Symposium on ELR, Rio de Janeiro, May 2008.

42. Mehrotra, Santosh (2008b) 'NREG Two Years On: Where do we go from here? http://www.indiaenvironmentportal.org.in/files/2 38.pdf 
ISSN: 2321-1091

Volume: 12 Issue: 01

Journal of Social Science Research

43. Menon, SudhaVenu (2008) 'Right to Information Act and NREGA: Reflections on Rajasthan'http://mpra.ub.uni-muenchen.de/7351/1/MPRA_paper_7351.pdf

44. Miller, Steven (1992), 'Remuneration systems for Labour Intensive investments: Lessons for Equity and Growth,' International Labour Review, Vol.131, 1992, No. 1

45. Mitchell W (2008) 'Assessing the wage transfer function and developing a minimum wage framework for the Expanded Public Works Programme in South Africa', Centre for Full Employment and Equity, University of Newcastle, Newcastle Australia.

46. Mukherjee ArghyaKusum and KunduAmit (2011): Impact of Swarna Jayanti Gram SwarojgarYojona (SGSY) on Health, Education and Women Empowerment. MPRA Paper No. 33258, posted 9. September 2011, 14:15 UTC.

47. National Urban Livelihoods Mission; Ministry of Housing and Urban Poverty Alleviation(MoHUPA) (2015): Training Module on Employment through Skill Training \& Placement for Capacity building of field functionaries of NULM.

48. Nayak, Nandini and KheraReetika (2009) 'Women workers and perceptions of the National Rural Employment Guarantee Act in India' http://www.faoilo. org/fileadmin/user_upload/fao_ilo/pdf/Papers/24_March/Nayak_-_formatted.pdf

49. NegiR.S., Singh Santosh and DhanaiRekha (2015): Impact Assessment of MGNREGA: Study of PauriGarhwal District of Uttarakhand, India.International Journal of Multidisciplinary and Current Research, Vol.3

50. Oakley, P. (1999) Organization, contracting and negotiation in development programmers and projects: A study of current practice at the community level. ILO, Geneva.

51. Prasad Dr. H. A. C., Sinha Dr. N. K. and Khan Riyaz A. (2013): Performance of Major Social Sector Schemes: A Sample Survey Report. Working Paper No.3/2013-DEA.

52. Rani M. Prameela (2015): Impact of Mgnrega on Life of People and Reforms. International Journal of Multidisciplinary Advanced Research Trends ISSN : 2349-7408 VOLUME 2, ISSUE 3, MARCH 2015.

53. Romero, Simon and William Neuman (2013): "Sweeping Protests in Brazil Pull Inan Array of Grievances." New York Times, 20 June, 2013.Salazar-Xirinachs, Jose M. (2008) 'Social Security and Employment: Perspectives on the Linkages', Presentation at the Asia-Pacific Regional High-Level Meeting on Socially Inclusive Strategies to Extend Social Security Coverage, New Delhi, India,

54. Samson, Melanie (2006) 'Waste Management Public Works Programmes - Creating the Conditions of the 'Second Economy', ' unpublished manuscript.

55. ShekharShreyes (2014): MGNREGA-Programme Details, Critical Analysis and Alternatives. Researching Reality Summer Internship 2014.Working paper: 325.

56. Stahlberg, StéphanieGimenez (2013): India's latest and largest workfare program: evaluation and recommendations.

57. UpenKonch (2015): Self-Employment Opportunities of Women through Self Help Groups (Shgs) Under Swarna Jayanti Gram SwarojgarYojana (Sgsy) In Assam. International Journal of Applied Research2015; 1(10): 665-671.

58. Vanaik, Anish and Siddhartha (2010) "Bank Payments: End of Corruption in NREGA? Economic \& Political Weekly EPW April 26, 2008 
ISSN: 2321-1091

Volume: 12 Issue: 01

Journal of Social Science Research

59. Wag (2010): Youth Entrepreneurship Strategy: an action plan for Wales 2010-15, Welsh Assembly Government/ HMSO.

60. Wolff J and Nivorozhkin A (2008): Start me up: 'The Effectiveness of a Self-Employment Programme for Needy Unemployed People in Germany', IAB Discussion Paper 2008/20, InstitutfürArbeitsmarktund Berufsforschung, Nuremberg.

61. Yunus, K. and Li, S. "Matching Job Skills with Needs", Business Times (1 October 2005).

62. Zhu Ling and Jiang Zhongyi (1995), "“Yigong-Daizhen” in China: A New Experience with Labor-Intensive Public Works in Poor Areas', Chapter 4 in J.von Braun (ed.), Employment for Poverty Reduction and Food Security, Washington D.C.: IFPRI. 